\title{
Soil morphological variations on the Taoyuan Terrace, Northwestern Taiwan: Roles of topography and groundwater
}

\author{
Yu-Shih Lin ${ }^{\mathrm{a}, \mathrm{b}, *}$, Yue-Gau Chen ${ }^{\mathrm{b}}$, Zueng-Sang Chen ${ }^{\mathrm{c}}$, Meng-Long Hsieh ${ }^{\mathrm{b}}$ \\ a Department of Geography, National Taiwan University, Taipei 106, Taiwan, R.O.C. \\ ${ }^{\mathrm{b}}$ Department of Geosciences, National Taiwan University, Taipei 106, Taiwan, R.O.C. \\ ${ }^{\mathrm{c}}$ Department of Agricultural Chemistry, National Taiwan University, Taipei 106, Taiwan, R.O.C.
}

Received 5 January 2004; received in revised form 29 November 2004; accepted 4 December 2004

Available online 3 February 2005

\begin{abstract}
To understand whether soils on the same geomorphic surface have similar properties, this study examines the morphology of soils developed on the 30-kyr-old Taoyuan Terrace, Northwestern Taiwan. Relationships among soil morphology, variations in the groundwater table, and soil forming processes were established based on field investigations and previously published datasets. The soil series in the study area can be grouped into seven types, including three homogeneous groups, two mottled groups, one gley group, and one reworked group. Fifteen hand-core samples collected in the field and borehole data were used to understand spatial variations in soil morphology. The results indicate that soil morphology on the southern Taoyuan Terrace changes systematically from the fore-edge to the back-edge: from red/orange soils to yellow soils, then to mottled soils, and finally to gley soils. The borehole data indicate that the groundwater table is generally parallel to the ground surface but drops significantly near the terrace fore-edge. This pattern matches with the observed soil toposequence, indicating that the pedogenic processes in the study area are mainly controlled by groundwater distribution determined by topography. Although soils on the terrace fore-edge have developed under the well-drained conditions that favor lateritization, at least two distinct soil types (i.e., red and orange) can be observed there, reflecting different geomorphological settings in a paleo-fluvial landscape. This work suggests that geomorphological and hydrological conditions should be examined carefully before using soil morphology for correlating geomorphic surfaces.
\end{abstract}

(C) 2005 Elsevier B.V. All rights reserved.

Keywords: Soil map; Soil morphology; Laterite; Soil toposequence; Geomorphic surfaces; Groundwater table

\footnotetext{
* Corresponding author. Department of Geosciences, National Taiwan University, Taipei 106, Taiwan, R.O.C. Fax: +88622363 6095 .

E-mail address: yushin1492@yahoo.com.tw (Y.-S. Lin).
}

\section{Introduction}

This study uses the term 'soil geomorphology', proposed by McFadden and Knuepfer (1990), to express the reciprocal relationship between landscape evolution and soil genesis. In Northwestern Taiwan, 
red soils known as 'laterites', occur extensively in the Taoyuan-Chungli area and have been used for brick making (Sivarajasingham et al., 1962). In previous geological studies in the Taoyuan-Chungli area, besides river-terrace elevation and radiocarbon ages, the degree of lateritization has been used as an index for terrace correlation $(\mathrm{Ku}, 1963$; Chen and Liu, 1991; Sung et al., 1997; Chuang et al., 2002). Use of this index requires the understanding of the basic processes of laterite formation. Pedologists in Taiwan have long been interested in the properties and genesis of laterites, particularly thick ones on higher fluvial terraces at about $200 \mathrm{~m}$ a.s.l. (Liang, 1971; Wan et al., 1985, 1986a,b). To understand complex laterite formation, pedosequences such as chronosequence and toposequence (Jenny, 1941) should be studied to evaluate the influence of each environmental factor. However, achieving this objective is difficult without appropriate geomorphological, geological, and pedological data. Lin (1991) attempted to perform such multidisciplinary research to establish the soil chronosequence for various geomorphic levels in the Taoyuan-Chungli area based on soil chemistry and mineralogy. However, the tacit assumption of Lin (1991) that soils on one geomorphic surface were morphologically identical has not been examined carefully. Indeed, Chen (1976) reported that soils on the Taoyuan-Chungli area are highly variable, although Chen's work has received only limited attention and has not been incorporated with geomorphological studies. A later study on soil toposequence in the coastal part of the Taoyuan-Chungli area (Hseu and Chen, 1996) also suggested that soils on one surface vary both in morphology and chemistry because of seasonal groundwater-table fluctuations. Similar conclusions have been reached in some other regions of the world such as central North Queensland (Coventry et al., 1983), NorthCentral Indiana (Evans and Franzmeier, 1986), and eastern Peru (Osher and Buol, 1998).

Soil morphology is important both for geomorphologists and soil scientists, because for the former, it provides a method to estimate the relative age of a geomorphic surface quickly in the field (e.g., Ota et al., 2002), while for the latter, it indicates drainage conditions and pedogenetic processes (Fanning and Fanning, 1989; Cornell and Schwertmann, 1996; Hseu and Chen, 1996). This study investigates the morphology of soils on the Taoyuan Terrace, the youngest broad terrace surface in the TaoyuanChungli area. This study for the first time focuses on the upland soil toposequence in the TaoyuanChungli area, in contrast to Hseu and Chen (1996) who studied only its coastal part. The objectives of this study are: (i) to map the distribution and variation of soil morphology on the broad Taoyuan Terrace; (ii) to explain the observed pattern of soil-morphological variations; and (iii) to discuss the potential for using the degree of lateritization as an index of terrace correlation.

\section{Study area}

The Taoyuan Terrace is located in Northwestern Taiwan, $50 \mathrm{~km}$ southwest of Taipei (Fig. 1). The Taoyuan Terrace is the youngest broad terrace surface in the Taoyuan-Chungli area, originally created as an alluvial fan by the paleo-Tahan River. The Tahan River, currently flowing in a northeastern direction, had flowed westwards into the sea before the Taoyuan Terrace formed (Chen and Liu, 1991). Due to tectonic activities, the paleo-Tahan River gradually migrated clockwise and left several terraces behind (Wang et al., 2002). These terraces are, from the highest to the lowest levels, the Hukou, Fukang, Yangmei, Talun, Chungli, and Taoyuan Terraces (Fig. 1b). The Taoyuan Terrace formed about $30 \mathrm{ka}$ when the paleo-Tahan River was captured by the paleo-Tanshui River (Chen and Liu, 1991), and it has experienced an incision of ca. $100 \mathrm{~m}$ deep (Fig. 1b). The Chieton and Nankan Rivers (Fig. 2) flow on the Taoyuan Terrace without deep down cutting, and their courses probably follow the abandoned channels of the paleo-Tahan River.

The Taoyuan Terrace is composed of Quaternary deposits, with cobbles overlain by finer alluvial material. The terrace has a longitudinal gradient of $1 \%$ to $7 \%$ and descends gradually from Shihmen Village towards the sea (Fig. 2). The average summer and winter temperatures in the study area are $28{ }^{\circ} \mathrm{C}$ and $14{ }^{\circ} \mathrm{C}$, respectively, and the mean annual rainfall over the past decade (1991-2000) is $2033 \mathrm{~mm}$ (Central Weather Bureau, 1983-2000). The average monthly evaporation peaks in July, but never exceeds the average monthly rainfall. The soil temperature and 


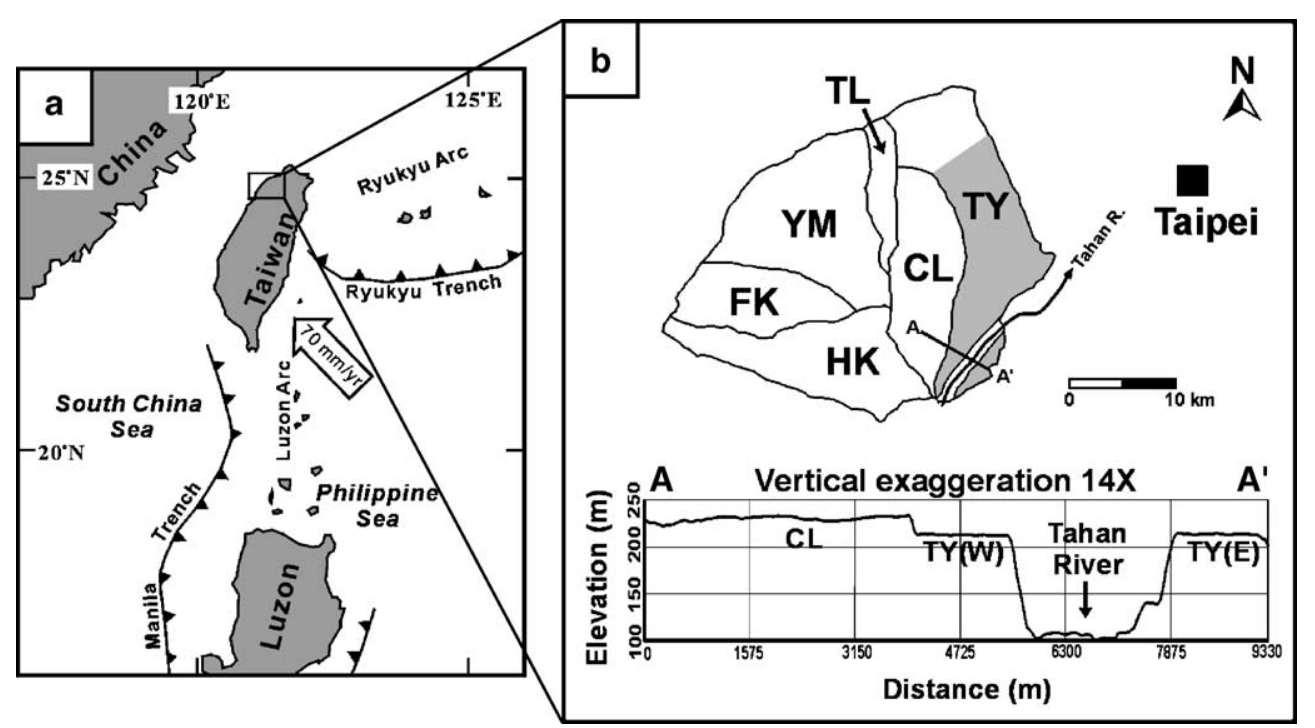

Fig. 1. Location maps of the study area. The Taoyuan Terrace is a set of the youngest broad terrace surfaces in the Taoyuan-Chungli area. The shade in panel (b) shows the coverage of the soil map in Fig. 2. The A- $\mathrm{A}^{\prime}$ profile displays the topographic relationship among the Chungli Terrace, Taoyuan Terrace, and the present floodplain of the Tahan River. Terrace surfaces: HK=Hukou Terrace; FK=Fukang Terrace; $\mathrm{YM}=$ Yangmei Terrace; $\mathrm{TL}=$ Talun Terrace; $\mathrm{CL}=$ Chungli Terrace; $\mathrm{TY}=$ Taoyuan Terrace.

moisture regimes of the study area are hyperthermic and udic. After the construction of irrigation systems and reservoirs in the 1960s, the major land use on the terrace changed from tea farming to rice paddy. During our fieldwork, soil sampling in paddy fields was deliberately avoided because of their anthraquic conditions (Chen, 1984).

\section{Material and methods}

\subsection{Soil map reclassification and field investigations}

A 1:25000 soil map in and around the Taoyuan Terrace (Chen, 1976) describes 30 soil series classified based on morphological and chemical characteristics, and each soil type was named after the location where it was discovered and described for the first time. For example, the Pc series (Table 1) stands for soils with a thick red oxic horizon and few mottles in the upper $100 \mathrm{~cm}$, and such a profile was first described in Pingchen $(\mathrm{Pc})$, a town located on the Chungli Terrace. Chen (1976) discussed the differences among these soil series based on some morphological characteristics such as soil thickness, color, mottling, soil depth to the Fe-Mn concretion, and plinthite. However, due to the unfamiliar nomenclature and the intricate classification, researchers in Taiwan have rarely used this jigsawlike soil map when dealing with the problems of soil geomorphology, although the map was compiled from abundant data. To utilize the map for a regional-scale study, we grouped the 30 soil types in Chen (1976) into seven major categories (Table 1; Fig. 2). Homogeneous soils are those with few mottles, and they were classified into red, orange, and yellow types based on matrix colors. Mottled soils contain well-developed redoximorphic characteristics such as concentrations and depletions, and their ratios generally increase with an increasing depth. The mottled soils were divided into red and yellow types based on matrix colors. Gley soils have a gley horizon in the lower part of the pedon. The reworked group includes soils that have undergone changes due to fluvial processes such as erosion, transportation, and redeposition.

Soil samples were collected from fifteen sites (TY1-1 to TY1-6, TY2-1 to TY2-5, and TY3-1 to TY3-4) between March and May of 2002 by handauger drilling to a depth of 1-1.5 m, except for TY11 and TY2-3 where samples were taken from outcrops (Fig. 3). The three groups of the sites, 
Table 1

Reclassification of soil series on the Taoyuan Terrace

\begin{tabular}{|c|c|c|c|c|c|c|c|}
\hline \multicolumn{2}{|c|}{ Reclassification } & \multicolumn{6}{|l|}{ Classification by Chen (1976) } \\
\hline \multirow[t]{2}{*}{ No. } & \multirow[t]{2}{*}{ Group } & \multirow[t]{2}{*}{ Profile characteristics } & \multirow[t]{2}{*}{ Color $^{\mathrm{a}}$} & \multirow[t]{2}{*}{$\begin{array}{l}\text { No Fe-Mn } \\
\text { concentration }^{\text {a }}\end{array}$} & \multicolumn{2}{|c|}{$\begin{array}{l}\text { Soil depth to the Fe-Mn } \\
\text { concentration }\end{array}$} & \multirow[t]{2}{*}{ Plinthite } \\
\hline & & & & & $<60 \mathrm{~cm}$ & $>60 \mathrm{~cm}$ & \\
\hline 1 & $\begin{array}{l}\text { Homogeneous } \\
\text { red soil }\end{array}$ & $40-120 \mathrm{~cm}$ : homogeneously red & $\mathrm{R}$ & Pc (Lk) & Sh & - & - \\
\hline 2 & $\begin{array}{l}\text { Homogeneous } \\
\text { orange soil }\end{array}$ & Yellowish red & YR & $\mathrm{Tc}$ & - & - & - \\
\hline \multirow[t]{2}{*}{3} & Homogeneous & Yellowish brown & YB & $\mathrm{Lt}, \mathrm{Cl}$ & - & - & $\mathrm{Hw}, \mathrm{Hi}$ \\
\hline & yellow soil & $<60 \mathrm{~cm}$ : with few red clods & $\mathrm{r}$ & & & & \\
\hline \multirow[t]{4}{*}{4} & Mottled red soil & $<90 \mathrm{~cm}:$ red & $\mathrm{R}$ & $\mathrm{Tl}$ & - & - & - \\
\hline & & $\begin{array}{l}>90 \mathrm{~cm} \text { : red, yellow, } \\
\text { and brown mottles }\end{array}$ & $\mathrm{R}+\mathrm{YB}$ & & & & \\
\hline & & Red under the topsoil with a & $\mathrm{R}$ & $\mathrm{Hk}$ & - & - & - \\
\hline & & few yellowish brown mottles & YB & & & & \\
\hline \multirow[t]{4}{*}{5} & Mottled & $<50-60 \mathrm{~cm}$ : yellowish brown & YB & $\mathrm{Ka}, \mathrm{Lc}$ & - & - & $\mathrm{Cw}$ \\
\hline & yellow soil & $\begin{array}{l}>50-60 \mathrm{~cm} \text { : red clods fewer } \\
\text { than yellowish brown clods }\end{array}$ & $\mathrm{R}+\mathrm{YB}$ & & & & \\
\hline & & $<50-60 \mathrm{~cm}$ : yellowish brown & YB(YR) & Tw & - & - & - \\
\hline & & $\begin{array}{l}>50-60 \mathrm{~cm} \text { : red clods more } \\
\text { than yellowish brown clods }\end{array}$ & $\mathrm{R}+\mathrm{YB}$ & & & & \\
\hline \multirow[t]{3}{*}{6} & Gley soil & $\begin{array}{l}\text { Yellowish brown }+ \text { gray with } \\
\text { a few red clods }\end{array}$ & $\mathrm{YB}+\mathrm{W}+\mathrm{R}(\mathrm{YR})$ & Fs & - & - & $\mathrm{Pu}$ \\
\hline & & $>60-90 \mathrm{~cm}$ : yellowish brown + gray & $\mathrm{YB} / \mathrm{YB}+\mathrm{W}$ & $\mathrm{Mt}, \mathrm{Tk}, \mathrm{Pa}$ & - & - & $\mathrm{Hh}, \mathrm{Si}$ \\
\hline & & $>40 \mathrm{~cm}$ : yellowish brown + gray & $\mathrm{YB}+\mathrm{W}$ & $\mathrm{Tn}, \mathrm{Ct}$ & - & - & $\mathrm{Hh}$ \\
\hline \multirow[t]{3}{*}{7} & Reworked soil & Red 50-90 cm: reach cobbles & $\mathrm{YR}(\mathrm{R})$ & $\mathrm{Sf}$ & - & St & - \\
\hline & & Red $<50 \mathrm{~cm}$ : reach cobbles & YR(R) & $\mathrm{Sa}$ & - & - & - \\
\hline & & $\begin{array}{l}\text { Dark yellow to yellowish brown } \\
<20-40 \mathrm{~cm} \text { : reach cobbles }\end{array}$ & $\mathrm{Y}(\mathrm{YR})$ to $\mathrm{YB}$ & Sk, Hg, Yp, Pd & - & - & - \\
\hline
\end{tabular}

${ }^{\text {a }}$ Blanketed descriptions show alteration due to long-term paddy cultivation.

TY1, TY2, and TY3, reflect different locations on the upland (Fig. 2). Besides thickness, color, mottling, and soil depth to the Fe-Mn concretion, this study also describes the texture, structure, and consistency of each horizon, since these three characters are fundamental for identifying soil horizons (Soil Survey Staff, 1998). In the following sections, however, we will not discuss the textural and structural properties because they are common to most soils on the Taoyuan Terrace (clay to silty clay and angular blocky to subangular blocky). Following the criteria of Schoeneberger et al. (1998), soils along a profile were described, then their samples were taken from each horizon and stored in plastic bags. The color and mottling of the samples were described in the laboratory and were compared with those recorded by Chen (1976).

\subsection{Borehole data analysis}

Previous studies have indicated a close relationship between soil drainage conditions and soil morphological features such as color and mottling (Vepraskas and Wilding, 1983; Hseu and Chen, 1996). We examined the validity of this relationship based on the distribution of the groundwater table in the Taoyuan Terrace. Following Huang (1995), we used 20 engineering borehole data collected by TANFB $(1986,1987)$ to construct a geologic crosssection with a water table (Fig. 4). These boreholes were drilled either in early summer or in late fall of 1986, and the two periods had different precipitation and evaporation levels. However, no marked anomaly in the water table among the boreholes was observed despite the fact that the data for the two 
periods were mixed, indicating that the seasonal effect on the snapshot obtained of the groundwater table is negligible.

\section{Results}

\subsection{Spatial variation of soil morphology inferred from the soil map}

Fig. 2 shows the simplified soil map of the Taoyuan Terrace. The map demonstrates the following spatial characteristics:

1) Between Yingge and Yuanshulin, the soil morphology changes systematically from the fore-edge to the back-edge of the terrace (like Fig. 1 in Woods, 1980), displaying a toposequence from red/orange soils to yellow soils, then to mottled soils, and finally to gley soils. The reworked soils also occur along the bank of the Chietong River. To the south of Yuanshulin, however, only the non-reworked homogeneous orange soil is dominant because of a weaker river flow.

2) There are morphological variations in soils along the banks of the Tahan River. Soils to the north of Chiaoai are uniformly red, while those to the south are orange. Both the soils occur continuously across a broad area, irrespective of variations in micro-topography.

3) Patches of the homogenous red soil exist in the northern coastal area, with their areas declining towards the coast. This observation indicates soil disturbances by fluvial processes.

\subsection{Spatial variation of soil morphology inferred from field records}

This study focuses on the southern part of the Taoyuan Terrace, that is, a proximal part of the paleofan less disturbed by fluvial activities. The 15 soil sampling sites are located in this area (Fig. 2). Fig. 3 and Table 2 show the photographs and information of some soil profiles. Both sites TY1-1 and TY1-2 exhibit homogeneous soils. Soils at TY1-1 (Fig. 3a), a 3-m-deep outcrop exposed in a construction site, are extremely red and contain only a few mottles in the upper $60 \mathrm{~cm}$, but yellow-colored mottles more abundantly occur around a depth of $100 \mathrm{~cm}$. The lack of groundwater seepage on the outcrop implies a deeper $(>3 \mathrm{~m})$ water table. These mottles, therefore, may have resulted from perching water at the contact between two distinct layers: an upper fine alluvium and a lower coarse alluvium with cobbles (Bohn et al., 1985; Hseu and Chen, 1996). Soils at TY1-2 contain a yellow matrix and red mottles. Their pedogenic mechanism remains unclear, but the site location suggests that the soils are transitional between the homogeneous and mottled soils. Mottled soils occur at TY1-3 and TY1-4. TY1-3 has a rather thin soil owing to its proximity to the active river channel. The mottles at TY1-3 show various colors including red, brownish red, yellow, and black. Although Chen (1976) suggested that gley soil occurs at TY1-3, our observation revealed that gley horizons are missing. Soils at TY1-4 contain well-developed mottles at a depth of $10 \mathrm{~cm}$. Their morphology changes from a yellow matrix with red and grey mottles in the upper $60 \mathrm{~cm}$ to a red matrix with yellow mottles at the lower depths. The upper yellow matrix might be related to the decomposition of organic matter under inundation (Fey, 1983; Schwertmann and Taylor, 1989). Soils at TY1-5 and TY1-6 do not contain any red clods. In the Bt horizon at TY1-5, white clods are coated with bright yellow material, but such coatings are not found in the $\mathrm{Bg}$ horizon (Fig. 3c). A strong odor of $\mathrm{H}_{2} \mathrm{~S}$ during our fieldwork indicates a highly reducing soil environment. Soils at TY1-6 have characteristics similar to those at TY1-5, with the gley horizon occurring at a shallow depth of $18 \mathrm{~cm}$.

Soils at the TY2 sites are similar to those at the TY1 sites. Highly homogeneous soils without observable mottles at TY2-1 are associated with the $\mathrm{Bt}$ horizon with an orange matrix. This matrix color differs from the redder color of the Bt horizon at TY1-1. Besides the high content of black manganese nodules, the morphological characteristics of soils at TY2-2 closely resemble those of TY1-2. Both the soil profiles at TY2-3 (Fig. 3b) and TY2-4 closely resemble the profile at TY1-4, but boundaries between horizons with different matrix colors are more distinct. The absence of a gley horizon at TY2-3 differs from the result of Chen (1976). Soils at TY2-5 on the back-edge of the terrace contain more iron than soils at TY1-5 and 


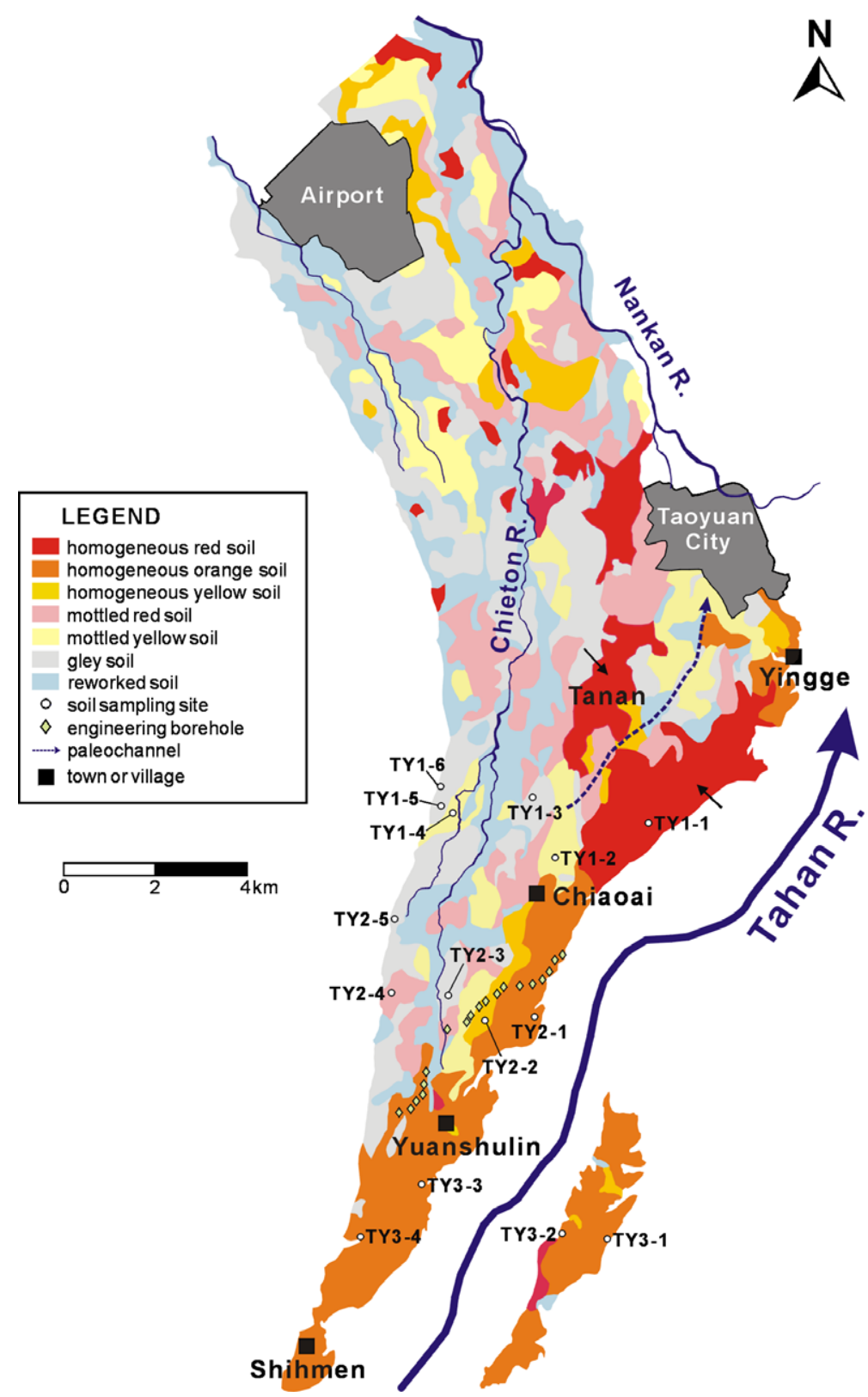

Fig. 2. Soil map of the Taoyuan Terrace, reclassified from Chen (1976). The path of the paleo-channel is inferred from 5-m-interval contours in topographic maps. Two black arrows point out two major patches of red soil along an abandoned paleo-channel. TY1, TY2, TY3: Three groups of soil sampling sites.

TY1-6 on the northern back-edge, probably due to its higher elevation. Large mottles of iron concentration in the upper $60 \mathrm{~cm}$ have made the horizon reddish, but the matrix color remains yellow. Below a depth of $60 \mathrm{~cm}$, the mottle content decreases, and the matrix color gradually changes from yellow to gray.

The TY3 sites in the southern study area display a different trend from the northern sites. On the eastern bank of the Tahan River, TY3-1 and TY3-2 are 
(a)
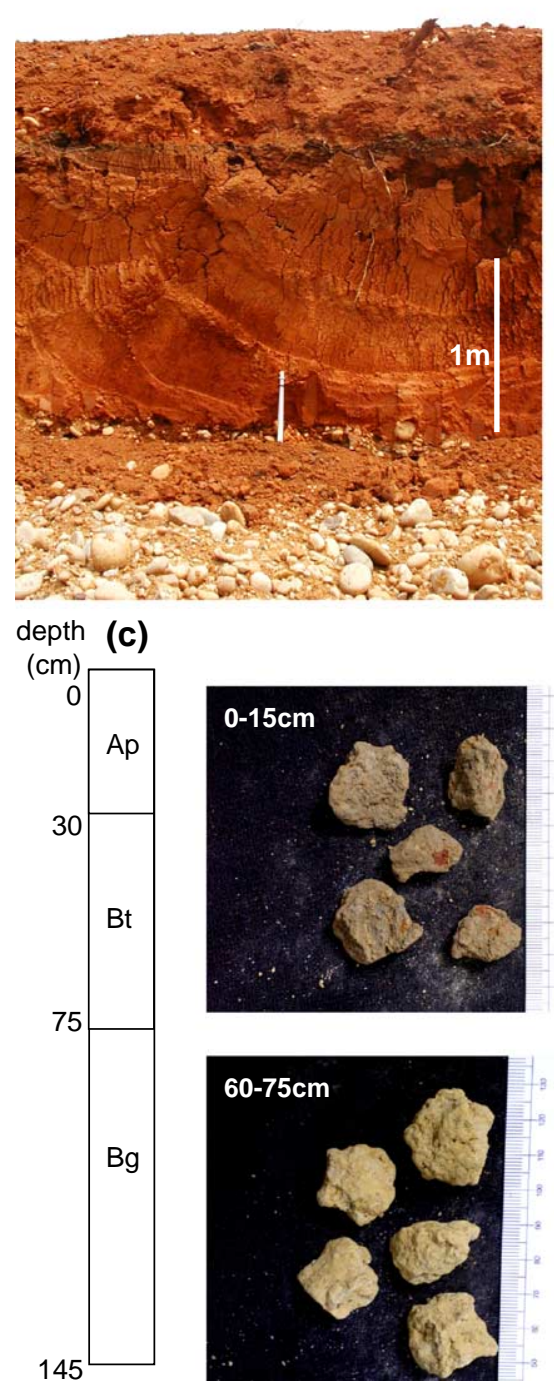
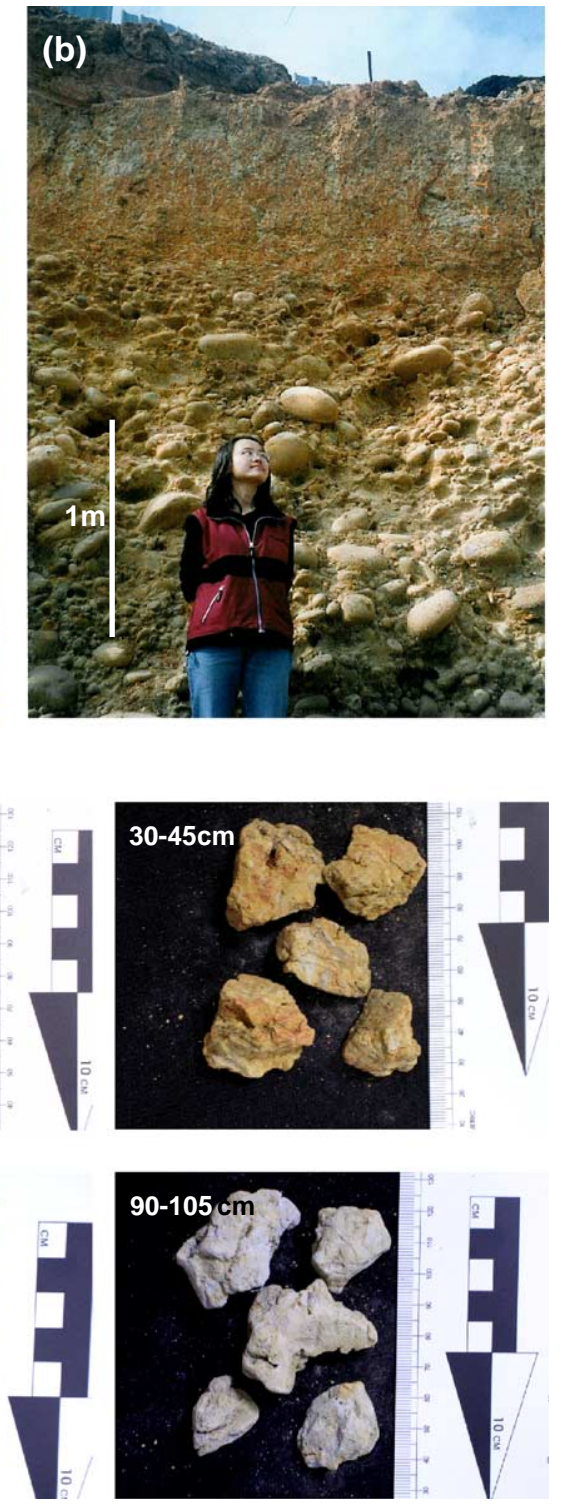

Fig. 3. (a) Homogeneous red soil at site TY1-1, located at a terrace fore-edge. (b) Mottled soil at site TY2-3, an outcrop formed by incision of the Chieton River. (c) Air-dried samples of gleyed soil collected from site TY1-5.

characterized by homogeneous orange soils with few mottles. Soils at TY3-3 and TY3-4 on the western bank are also homogeneous, but the matrix at TY3-4 is more yellowish than that at the other three sites.

To summarize, the soils on the Taoyuan Terrace are variable from place to place but display non-random spatial distribution patterns. Because soils at only two sites (TY1-3 and TY2-3) did not match the soil map by Chen (1976), the accuracy of the map is estimated to be $80 \%$ to $90 \%$.

\subsection{Groundwater table}

The geological cross-section reconstructed from engineering borehole data demonstrates that the capping soil layer pinches out towards the Chieton 
Table 2

Description of soil profiles at representative sample sites based on field observations

\begin{tabular}{|c|c|c|c|c|c|c|c|c|c|}
\hline \multirow[t]{2}{*}{ Sample sites } & \multirow[t]{2}{*}{ Horizon } & \multirow[t]{2}{*}{ Depth (cm) } & \multirow[t]{2}{*}{ Matrix color } & \multicolumn{3}{|l|}{ Mottle $^{a}$} & \multirow[t]{2}{*}{ Texture $^{\mathrm{b}}$} & \multirow[t]{2}{*}{ Structure $^{c}$} & \multirow[t]{2}{*}{ Consistence $^{\mathrm{d}}$} \\
\hline & & & & Color & Size & Abundance & & & \\
\hline \multirow[t]{10}{*}{ TY1-1 } & \multirow[t]{2}{*}{$\mathrm{Bt}$} & $0-20$ & $2.5 \mathrm{YR} 4 / 8$ & - & - & - & $\mathrm{C}$ & abk & vfi \\
\hline & & $20-40$ & $2.5 \mathrm{YR} 4 / 8$ & $2.5 Y 5 / 3$ & 2 & $\mathrm{c}$ & $\mathrm{C}$ & abk & vfi \\
\hline & \multirow[t]{8}{*}{ Btv } & $40-60$ & $10 \mathrm{R} 4 / 8$ & $10 \mathrm{R} 4 / 2$ & 3 & $\mathrm{~m}$ & $\mathrm{C}$ & sbk & $\mathrm{fi}$ \\
\hline & & & & $2.5 \mathrm{Y} 7 / 6$ & 2 & $\mathrm{c}$ & & & \\
\hline & & $60-80$ & 10R4/8 & 7.5YR6/8 & 3 & $\mathrm{~m}$ & $\mathrm{C}$ & sbk & fi \\
\hline & & & & $2.5 \mathrm{Y} 4 / 1$ & 3 & $\mathrm{c}$ & & & \\
\hline & & & & $2.5 Y 7 / 6$ & 2 & $\mathrm{f}$ & & & \\
\hline & & $80-100$ & $10 \mathrm{R} 4 / 8$ & $2.5 Y 6 / 8$ & 4 & $\mathrm{~m}$ & $\mathrm{SiC}$ & sbk & fi \\
\hline & & $100-120$ & 10R4/8 & $2.5 \mathrm{Y} 6 / 8$ & 4 & $\mathrm{~m}$ & $\mathrm{SiC}$ & sbk & $\mathrm{fr}$ \\
\hline & & $120-140$ & 10R4/8 & $2.5 \mathrm{Y} 6 / 6$ & 4 & $\mathrm{~m}$ & $\mathrm{SiC}$ & sbk & $\mathrm{fr}$ \\
\hline \multirow[t]{3}{*}{ TY3-3 } & Ap & $0-20$ & $7.5 \mathrm{YR} 4 / 4$ & - & - & - & $\mathrm{CL}$ & abk & $\mathrm{fr}$ \\
\hline & \multirow[t]{2}{*}{$\mathrm{Bt}$} & $20-35$ & $5 Y R 4 / 6$ & 2.5YR4/1 & 2 & $\mathrm{f}$ & $\mathrm{C}$ & abk & $\mathrm{fr}$ \\
\hline & & $35-140$ & $5 \mathrm{YR} 4 / 6$ & 2.5YR4/1 & 1 & $\mathrm{f}$ & $\mathrm{C}$ & abk & $\mathrm{fr}$ \\
\hline \multirow[t]{7}{*}{ TY3-4 } & \multirow[t]{2}{*}{ Ap } & $0-20$ & $2.5 \mathrm{Y} 4 / 3$ & $7.5 \mathrm{YR} 5 / 8$ & 1 & $\mathrm{f}$ & $\mathrm{SiL}$ & abk & $\mathrm{fi}$ \\
\hline & & $20-35$ & $10 \mathrm{YR} 3 / 4$ & 10YR6/8 & 2 & $\mathrm{f}$ & $\mathrm{SiL}$ & abk & fi \\
\hline & \multirow[t]{5}{*}{$\mathrm{Bt}$} & $35-60$ & 7.5YR4/6 & 7.5YR5/8 & 1 & $\mathrm{f}$ & $\mathrm{C}$ & abk & $\mathrm{fi}$ \\
\hline & & $60-80$ & $7.5 \mathrm{YR} 4 / 6$ & 7.5YR5/8 & 1 & $\mathrm{f}$ & $\mathrm{C}$ & abk & $\mathrm{fi}$ \\
\hline & & $80-95$ & $10 \mathrm{YR} 4 / 6$ & - & - & - & $\mathrm{C}$ & abk & $\mathrm{fr}$ \\
\hline & & $95-115$ & $2.5 \mathrm{Y} 4 / 3$ & - & - & - & $\mathrm{C}$ & sbk & vfr \\
\hline & & $115-130$ & 10YR4/4 & 7.5YR5/6 & 2 & $\mathrm{c}$ & $\mathrm{C}$ & sbk & vfr \\
\hline \multirow{8}{*}{ TY1-2 } & Ap & $0-10$ & $10 \mathrm{YR} 3 / 6$ & $2.5 \mathrm{YR} 4 / 8$ & 2 & $\mathrm{~m}$ & SL & $\mathrm{gr}$ & lo \\
\hline & $\mathrm{Bw}$ & $10-20$ & $2.5 \mathrm{YR} 5 / 3$ & 10YR6/8 & 1 & $\mathrm{f}$ & $\mathrm{CL}$ & sbk & $\mathrm{fr}$ \\
\hline & & $20-37$ & $2.5 \mathrm{Y} 7 / 8$ & $2.5 \mathrm{Y} 7 / 8$ & 2 & $\mathrm{f}$ & $\mathrm{C}$ & sbk & $\mathrm{fr}$ \\
\hline & $\mathrm{Bt}$ & $37-72$ & $2.5 Y 5 / 6$ & 7.5YR5/8 & 1 & $\mathrm{f}$ & $\mathrm{C}$ & abk & $\mathrm{fi}$ \\
\hline & Btv & $72-104$ & $2.5 Y 5 / 6$ & 5YR5/6 & 3 & $\mathrm{~m}$ & $\mathrm{C}$ & abk & fi \\
\hline & & & & 5YR5/1 & 3 & $\mathrm{c}$ & & & \\
\hline & & $104-110$ & $2.5 Y 5 / 6$ & $5 Y R 5 / 6$ & 3 & $\mathrm{~m}$ & $\mathrm{C}$ & $\mathrm{m}$ & $\mathrm{D}$ \\
\hline & & & & 5YR5/1 & 3 & $\mathrm{c}$ & & & \\
\hline TY2-3 & Ap & $0-7$ & $2.5 \mathrm{Y} 3 / 2$ & - & - & - & $\mathrm{L}$ & $\mathrm{gr}$ & $\mathrm{fr}$ \\
\hline & $\mathrm{Bt}$ & $7-50$ & $2.5 Y 5 / 6$ & 5 YR5/8 & 2 & $\mathrm{c}$ & $\mathrm{C}$ & abk & fi \\
\hline & Btv & $50-73$ & 7.5YR5/6 & $2.5 \mathrm{YR} 4 / 6$ & 3 & $\mathrm{c}$ & $\mathrm{SiC}$ & sbk & $\mathrm{fi}$ \\
\hline & & & & $10 \mathrm{YR} 7 / 2$ & 3 & $\mathrm{~m}$ & & & \\
\hline & & $73-90$ & 7.5YR5/6 & $2.5 \mathrm{YR} 4 / 6$ & 3 & $\mathrm{f}$ & $\mathrm{SiC}$ & sbk & fi \\
\hline & & & & 10YR6/2 & 3 & $\mathrm{~m}$ & & & \\
\hline & & $90-110$ & $2.5 \mathrm{YR} 4 / 6$ & 7.5YR5/6 & 3 & $\mathrm{~m}$ & $\mathrm{SiC}$ & sbk & $\mathrm{fr}$ \\
\hline & & & & 10YR6/2 & 1 & $\mathrm{c}$ & & & \\
\hline & & $110-130$ & $2.5 \mathrm{YR} 4 / 6$ & 7.5YR5/6 & 3 & $\mathrm{~m}$ & $\mathrm{SiC}$ & sbk & $\mathrm{fr}$ \\
\hline & & & & 10YR6/2 & 1 & $\mathrm{c}$ & & & \\
\hline TY2-5 & Ap & $0-25$ & $2.5 \mathrm{Y} 3 / 2$ & 10YR5/8 & 2 & $\mathrm{c}$ & $\mathrm{L}$ & abk & fr and BR \\
\hline & Btv & $25-45$ & $10 \mathrm{YR} 5 / 8$ & 2.5YR4/8 & 2 & $\mathrm{~m}$ & $\mathrm{C}$ & sbk & vfr and SD \\
\hline & & & & $2.5 \mathrm{Y} 8 / 2$ & 2 & $\mathrm{c}$ & & & \\
\hline & & $45-60$ & 10YR6/8 & $2.5 \mathrm{YR} 4 / 8$ & 3 & $\mathrm{~m}$ & $\mathrm{SiC}$ & sbk & fr and BR \\
\hline & & & & 10YR8/1 & 1 & $\mathrm{f}$ & & & \\
\hline & & $60-70$ & $10 \mathrm{YR} 5 / 8$ & $5 Y R 5 / 8$ & 2 & $\mathrm{c}$ & $\mathrm{C}$ & sbk & lo and D \\
\hline & & & & 7.5YR8/1 & 2 & $\mathrm{c}$ & & & \\
\hline & & $70-80$ & 10YR6/8 & 10YR8/1 & 2 & $\mathrm{c}$ & $\mathrm{C}$ & sbk & fr and D \\
\hline & & $80-95$ & $2.5 \mathrm{Y} 6 / 8$ & 5 YR5/8 & 1 & $\mathrm{c}$ & $\mathrm{C}$ & sbk & vfr and D \\
\hline & & & & 10YR8/1 & 2 & $\mathrm{c}$ & & & \\
\hline & $\mathrm{Bg}$ & $95-115$ & $2.5 \mathrm{Y} 6 / 8$ & $2.5 Y 7 / 6$ & 2 & $\mathrm{~m}$ & $\mathrm{C}$ & $\mathrm{m}$ & vfr and D \\
\hline & & & & $2.5 Y 8 / 1$ & 2 & $\mathrm{c}$ & & & \\
\hline & & $115-125$ & $2.5 \mathrm{Y} 6 / 6$ & $2.5 \mathrm{Y} 8 / 1$ & 3 & $\mathrm{~m}$ & $\mathrm{C}$ & $\mathrm{m}$ & vfr and D \\
\hline & & & & $2.5 \mathrm{Y} 6 / 8$ & 2 & $\mathrm{c}$ & & & \\
\hline
\end{tabular}


Table 2 (continued)

\begin{tabular}{|c|c|c|c|c|c|c|c|c|c|}
\hline \multirow[t]{2}{*}{ Sample sites } & \multirow[t]{2}{*}{ Horizon } & \multirow[t]{2}{*}{ Depth $(\mathrm{cm})$} & \multirow[t]{2}{*}{ Matrix color } & \multicolumn{3}{|l|}{ Mottle $^{\mathrm{a}}$} & \multirow[t]{2}{*}{ Texture $^{\mathrm{b}}$} & \multirow[t]{2}{*}{ Structure $^{\mathrm{c}}$} & \multirow[t]{2}{*}{ Consistence $^{\mathrm{d}}$} \\
\hline & & & & Color & Size & Abundance & & & \\
\hline & & $125-150$ & $2.5 \mathrm{Y} 8 / 1$ & $2.5 \mathrm{Y} 6 / 8$ & 3 & $\mathrm{~m}$ & $\mathrm{C}$ & $\mathrm{m}$ & vfr and SD \\
\hline & & & & $2.5 Y 7 / 6$ & 3 & $\mathrm{c}$ & & & \\
\hline \multirow[t]{8}{*}{ TY1-5 } & Ap & $0-15$ & $10 Y R 3 / 3$ & $2.5 \mathrm{YR} 3 / 6$ & 1 & $\mathrm{f}$ & $\mathrm{L}$ & sbk & lo \\
\hline & & $15-30$ & $7.5 \mathrm{YR} 3 / 3$ & $2.5 \mathrm{YR} 3 / 6$ & 2 & $\mathrm{f}$ & $\mathrm{L}$ & sbk & $\mathrm{fr}$ \\
\hline & $\mathrm{Bg}$ & $30-45$ & 10YR8/1 & 10YR7/8 & 2 & $\mathrm{~m}$ & $\mathrm{C}$ & sbk & fi \\
\hline & & & & 2.5 YR4/8 & 2 & $\mathrm{c}$ & & & \\
\hline & & $45-60$ & 10YR8/1 & 10YR6/8 & 2 & $\mathrm{~m}$ & $\mathrm{C}$ & sbk & fi \\
\hline & & $60-75$ & 10YR8/1 & 10YR6/8 & 2 & $\mathrm{~m}$ & $\mathrm{C}$ & sbk & fi and SD \\
\hline & $\mathrm{Bv}$ & $75-90$ & $2.5 Y 8 / 1$ & 10YR6/8 & 2 & $\mathrm{~m}$ & $\mathrm{C}$ & $\mathrm{m}$ & $\mathrm{D}$ \\
\hline & & $90-145$ & $2.5 \mathrm{Y} 7 / 1$ & $2.5 \mathrm{Y} 8 / 6$ & 1 & $\mathrm{f}$ & $\mathrm{C}$ & $\mathrm{m}$ & $\mathrm{D}$ \\
\hline
\end{tabular}

${ }^{a}$ Mottle size: $1=$ fine; $2=$ medium; $3=$ coarse; $4=$ very coarse. Mottle abundance: $\mathrm{f}=$ few; $\mathrm{c}=$ common; $\mathrm{m}=$ many.

b Texture: $\mathrm{CL}=$ clay loam; $\mathrm{SiC}=$ silty clay; $\mathrm{SiL}=$ silty loam; $\mathrm{L}=$ loam; $\mathrm{C}=$ clay.

${ }^{c}$ Structure: abk=angular blocky; sbk=subangular blocky; gr=granular; $\mathrm{m}=$ massive.

${ }^{d}$ Consistence: $l o=$ loose, vfr=very friable, fr=friable, fi=firm, vfi=very firm; $B R=$ brittle, $S D=$ semi-deformable, $D=$ deformable.

River (Fig. 4), showing the influence of fluvial processes. Some boreholes (C-51-1, B-49-1, B-48-5, B-48-3, B-48-2, B-47-4, and W-46-2) show that the matrix of the upper cobble layer primarily comprises of clay minerals, which may have been leached by gravimetric water. This illuviated clay reduces the permeability of the cobble layer, and thus influences the drainage condition of the overlaying soil. However, Fig. 4 indicates that local variations in the thickness of the cobble layer scarcely affect groundwater table positions. Additionally, the groundwater table to the west of B-48-1 basically follows the surface topography (Fig. 4). In contrast, to the east of B-48-1, the groundwater table drops

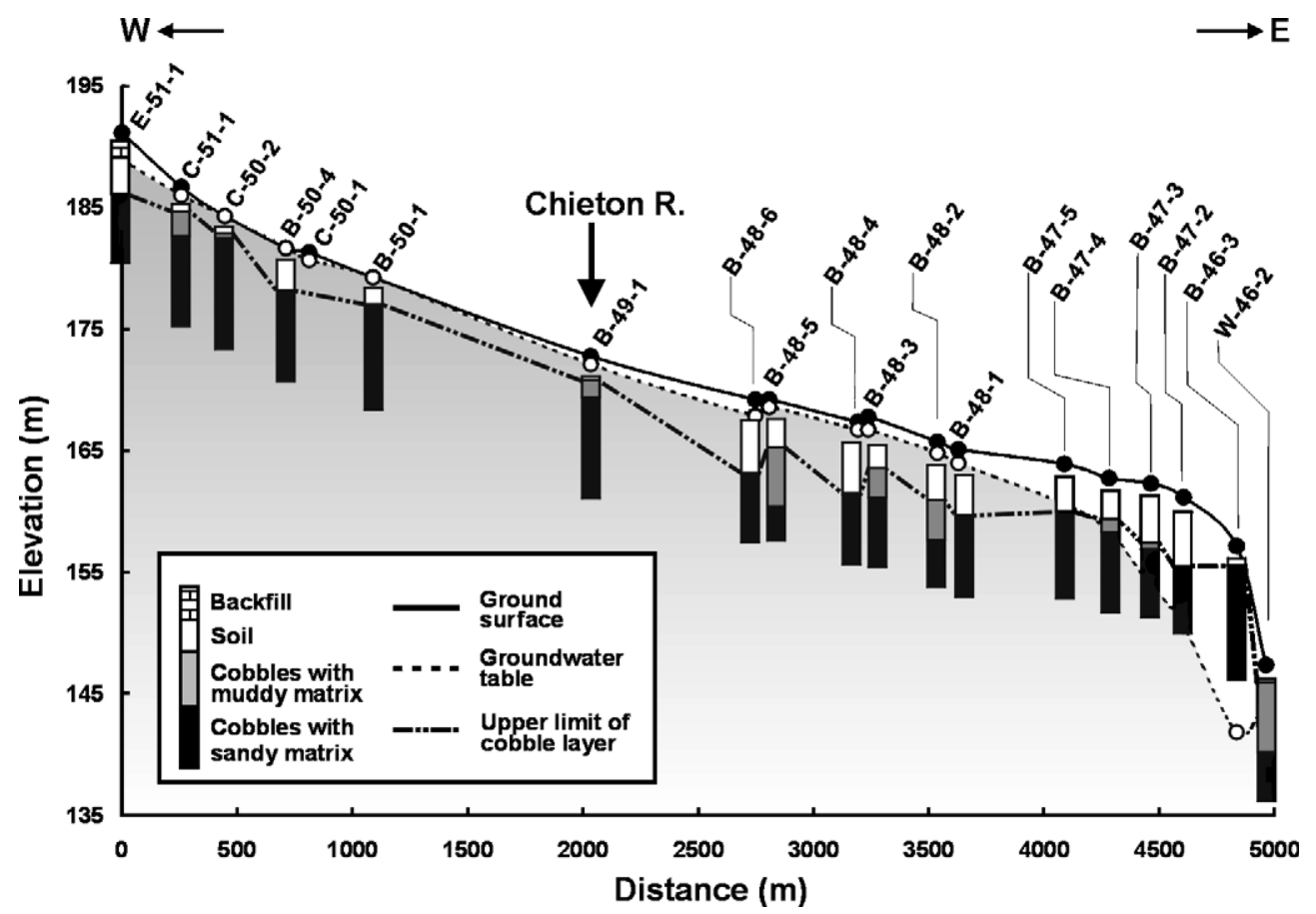

Fig. 4. Inferred groundwater table in the Taoyuan Terrace. The location of the groundwater table is consistent not with lithology but with terrace topography. 
from the land surface and attains to a depth of $10 \mathrm{~m}$ at B-46-3. B-48-1 corresponds to the boundary of the homogenous and mottled soils. No groundwater table information is available for a small area near the back-edge (see Fig. 2).

\section{Discussion}

\subsection{Soil distribution pattern}

In the southern study area, both the simplified soil map and field observation show the same soil toposequence from the fore-edge to the back-edge, namely, from homogenous red/orange soils to yellow soils, then to mottled soils, and finally to gley soils. This pattern probably reflects hydrological conditions, which is indicated by the groundwater table inferred from the engineering borehole data. Assuming that the observed pattern of the groundwater table stretches across the southern Taoyuan Terrace, we propose a simple model for explaining the observed soil toposequence (Fig. 5). Both the lateral groundwater recharge and discharge of the Taoyuan Terrace result in different drainage conditions between the back- and the fore-edges. In addition to vertical recharge from precipitation, the Chungli Terrace, a higher region to the west of the study area, provides lateral groundwater recharge toward the lower Taoyuan Terrace.
Since the lateral recharge may have kept the groundwater table permanently high along the back-edge of the terrace (Zone I in Fig. 5), it facilitates the formation of the gley horizon under the reducing soil environment. This explanation is supported by our field observation that the groundwater table nearly reaches the land surface. In the transition zone between the back- and fore-edges (Zone II in Fig. 5), the mottled soils prevail due to a better drainage condition than in the back-edge. Soils there are not constantly saturated, and their conditions alternate between oxic and suboxic regimes, resulting in abundant redoximorphic characteristics. In the foreedge (Zone III in Fig. 5), where the moderately drained soils tend to grade into well-drained units (Daniels et al., 1967), homogeneous soils result from a strong lateral discharge process. The smaller E-W width of the Taoyuan Terrace to the south of Yuanshulin could make the lateral discharge stronger. Therefore, not gley or mottled soils but homogeneous soils take place (Fig. 2).

Based on the above argument, this study proposes that soils on the Taoyuan Terrace have undergone different pedogenic processes. Latosolization, the production of residual sesquioxide-rich materials by strong leaching processes with properties of, or closely akin to, a homogeneous red oxic horizon (Soil Survey Staff, 1998), dominates in the fore-edge. Furthermore, lateritization, the traditional term once
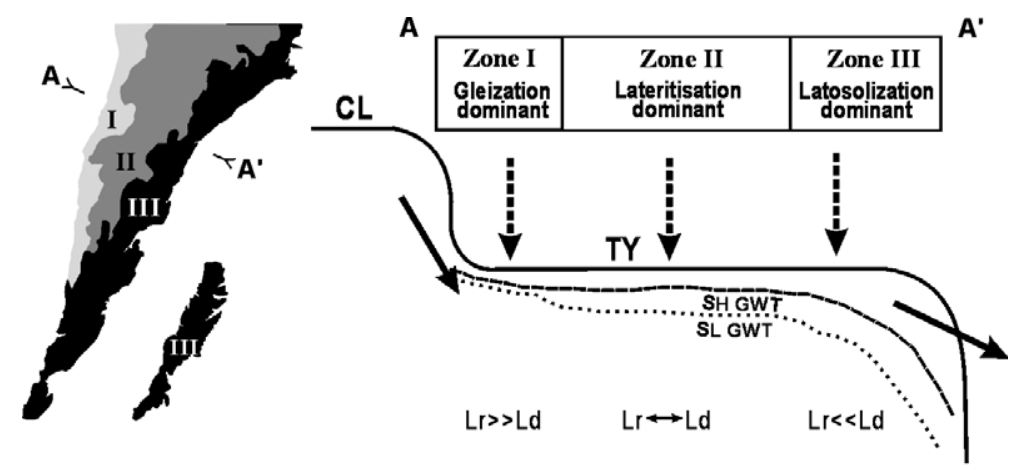

SH GWT: seasonal high groundwater table

SL GWT: seasonal low groundwater table

Lr: lateral recharge

Ld: lateral discharge

$\rightarrow$ meteoric water

groundwater

Fig. 5. A model for explaining soil morphological variations on the Taoyuan Terrace. Both lateral recharge and discharge cause different drainage conditions between the back- and fore-edges, leading to different pedogenetic processes. CL: Chungli Terrace. TY: Taoyuan Terrace. 
used to describe the formation of laterite but now applied only to the genesis of iron 'oxides'-enriched plinthite (Fanning and Fanning, 1989), dominates to form mottled soils in the transition zone between the fore- and back-edges, due to oxidation and precipitation of dissolved Fe from groundwater. Finally, gleization dominates in the back-edge, forming reduced low-chroma matrices by removing iron from poorly drained soils. These interpretations are consistent with some theories of laterite formation in that the 'extra' iron has been derived from lateral water movement from gleyed upland depressions (Ollier and Pain, 1996; Valeton, 1999).

To verify the influence of groundwater on the soil development, long-term field monitoring of the groundwater table is required. Our inference is tentative because it is based only on the relationship between the groundwater table location and terrace topography inferred from a limited number of engineering borehole data.

\subsection{Origin of homogeneous red and orange soils}

The simplified soil map (Fig. 2) demonstrates that soils along the fore-edge are not always identical and our fieldwork has confirmed this observation. To quantify this difference in soil characteristics, the Redness Index (RI=Hue* $\times$ Lightness/Chroma) (Hurst, 1977) for the homogeneous red and orange soils was calculated. Equivalent Hue and Hue* values are: $5 \mathrm{R}=5,7.5 \mathrm{R}=7.5, \quad 10 \mathrm{R}=10,2.5 \mathrm{YR}=12.5,5 \mathrm{YR}=15$, $7.5 \mathrm{YR}=17.5$, and $10 \mathrm{YR}=20$. Hurst (1977) proposed that the value of RI is inversely proportional to the content of $\mathrm{Fe}_{2} \mathrm{O}_{3}$ (Table 3). Lin (1991) concluded that RI decreases with an increasing degree of laterite development; hence, this index may provide a way to measure the relative age of a geomorphic surface. However, in the present study, the difference in the RI values between red and orange soils on the same geomorphic surface is about five (Table 3), nearly as large as that between red soils from different levels of geomorphic surfaces (Lin, 1991). In other words, intra-surface variations in RI may be as large as intersurface variations, implying that RI is not an appropriate age indicator.

One possible explanation for the origin of the homogeneous orange soil on the Taoyuan Terrace is related to paleoclimate. As Chen (1976) noted, this
Table 3

Munsell color and the Redness Index $\left(\mathrm{RI}=\mathrm{H}^{*} \mathrm{~L} / \mathrm{C}\right)$ of soil samples

\begin{tabular}{|c|c|c|c|c|}
\hline $\begin{array}{l}\text { Sample } \\
\text { ID }\end{array}$ & $\begin{array}{l}\text { Munsell } \\
\text { color }\end{array}$ & $\begin{array}{l}\text { Terrace } \\
\text { Surface }\end{array}$ & $\mathrm{RI}=\mathrm{H}^{*} \mathrm{~L} / \mathrm{C}^{\mathrm{a}}$ & $\mathrm{Fe}_{2} \mathrm{O}_{3}(\%)$ \\
\hline \multicolumn{5}{|c|}{ Natural samples used in Hurst (1977) } \\
\hline 8 & 10YR 8/1 & & 160.0 & 0.37 \\
\hline 4 & 10YR $7 / 2$ & & 70.0 & 0.75 \\
\hline 5 & $7.5 \mathrm{YR} 7 / 4$ & & 30.6 & 1.37 \\
\hline 7 & 10YR 7/4 & & 35.0 & 1.87 \\
\hline 3 & $\begin{array}{l}7.5 \mathrm{YR} 7 / 6 \\
\text { to } 5 \mathrm{YR} 7 / 6\end{array}$ & & 19.0 & 4.37 \\
\hline 13 & 5 YR $5 / 8$ & & 9.4 & 5.86 \\
\hline 2 & $5 Y R 6 / 8$ & & 11.3 & 5.97 \\
\hline 9 & 7.5YR 7/6 & & 20.4 & 7.49 \\
\hline 12 & 5 YR $5 / 6$ & & 12.5 & 7.60 \\
\hline 10 & 2.5 YR $5 / 8$ & & 7.8 & 7.68 \\
\hline 11 & 5YR 5/8 & & 9.4 & 8.48 \\
\hline 6 & $5 Y R 6 / 6$ & & 15.0 & 9.84 \\
\hline 1 & 5YR 5/8 & & 9.4 & 11.04 \\
\hline $6 \mathrm{~A}$ & 7.5YR 6/8 & & 13.1 & 15.60 \\
\hline $12 \mathrm{~A}$ & $7.5 \mathrm{YR} 6 / 8$ & & 13.1 & 16.70 \\
\hline \multicolumn{5}{|c|}{ Soil samples used in Lin (1991) } \\
\hline TY & 5YR 5/6 & Taoyuan & 12.5 & \\
\hline CLi2 & $2.5 \mathrm{YR} 4 / 8$ & Chungli & 6.3 & \\
\hline TLC2 & 10R $4 / 8$ & Hukou & 5.0 & \\
\hline \multicolumn{5}{|c|}{ Soil samples used in this study } \\
\hline TY3-3 & $5 Y R 4 / 6$ & Taoyuan & 10.0 & \\
\hline TY1-1 & 10R 4/8 & Taoyuan & 5.0 & \\
\hline
\end{tabular}

${ }^{a}$ Equivalent $\mathrm{H}$ and $\mathrm{H}^{*}$ values: $5 \mathrm{R}=5 ; 7.5 \mathrm{R}=7.5 ; 10 \mathrm{R}=10$; $2.5 \mathrm{YR}=12.5 ; 5 \mathrm{YR}=15 ; 7.5 \mathrm{YR}=17.5 ; 10 \mathrm{YR}=20$ (Hurst, 1977).

soil tends to occur along the riverbanks of the Tahan River (Fig. 2), indicating that it may have originated from frequent floods before the piracy of the paleoTahan River by the paleo-Tanshui River at about 30 ka. After the piracy, these fine flood deposits were left in a well-drained condition. A cool climate at that time was unfavorable for the formation of red soils, and consequently only orange soils developed. This idea is consistent with the fact that other terraces in Taiwan covered mostly with red soils generally have radiocarbon ages older than $30 \mathrm{ka}$ (Ota et al., 2002).

If the above inference is correct, why do the red and orange soils coexist on the Taoyuan Terrace? Based on 5-m-interval contour lines on a 1:5000 topographic map, a paleo-channel could be traced in an area between Taoyuan City and Chiaoai (Fig. 2). Two patches of the homogeneous red soil (marked with arrows in Fig. 2) are distributed along the higher overbank zone of the paleo-channel. Such a minor 
topographical high may have improved drainage conditions, giving rise to red soils rather than orange soils. We suggest that the smaller patches of the homogeneous red soil in the northern study area also correspond to overbank zones in a paleo-fluvial landscape, although its verification is difficult because of the poor preservation of the original landforms due to fluvial dissection.

\subsection{Implications for terrace correlation}

Daniels et al. (1967) concluded that soil characteristics depend upon how long a site has been well drained rather than the age of a geomorphic surface. From the present case study, two factors can be proposed to influence drainage conditions and soil development on a single terrace surface: terracesurface topography and relative locations of soils in a broader fluvial landscape. The location of the Taoyuan Terrace relative to the adjacent higher area affects groundwater table variations and soil morphology. The higher area serves as a recharge area, resulting in poorly drained soils on their lower neighbor. The general terrace shape also controls drainage efficiency. For example, soils on the narrow terrace between Yuanshulin and Shihmen are nearly completely free of gley horizons and mottles (Fig. 2).

Soils also record their own history in relation to small-scale fluvial landforms. Soil profiles in a dynamic fluvial system reflect the rates of past sediment accumulation and drainage efficiency (Walker and Coventry, 1976). In high overbank zones rarely affected by river flows, stable conditions and good drainage favor pedogenesis with latosolization. In the Taoyuan Terrace, the patches of the homogeneous red soil can be found where paleo-fluvial landscapes persisted for a long time due to weaker erosion.

To summarize, the 30-kyr-old Taoyuan Terrace has a strong intra-surface variation in soil properties, generated by local differences in the groundwater table and fluvial processes, and the variation particularly increases in areas near the back-edge of the terrace surface. This fact reflects a relatively short period of soil formation because soils on older, highly dissected terraces are morphologically identical throughout the surface (Lin, 2004). Lastly, soils developed along the fore-edge of a terrace surface seem to be useful for terrace correlation, since their best drainage conditions permit ideal soil development. However, the formation of such 'ideal soils' may be disturbed by other factors, such as the imprint of a preexisting fluvial landscape. Therefore, to use the degree of lateritization as an index for terrace correlation, it is important to find a characteristic unique to topographic surfaces with a certain range of ages. In the case of the Taoyuan Terrace, the existence of the homogeneous orange soil rather than that of the homogeneous red soil may provide an indicator applicable to terrace correlation.

\section{Conclusions}

This study has investigated soils on the Taoyuan Terrace in Taiwan and revealed a soil toposequence from the terrace fore-edge to the back-edge. The groundwater table profile estimated from borehole data indicates that lateral groundwater recharge and discharge have accounted for major morphological variations of soils. This study has also discovered the secondary soil morphological variations along the banks of the Tahan River, resulted from differences in their relative positions in a paleo-fluvial landscape. Although soils on the terrace edge are generally developed in a well-drained condition favorable for lateritization and can be regarded as an indicator of terrace correlation, a detailed soil drainage history should be reconstructed before applying soil morphology to terrace correlation.

The method used in this study, including both the rearrangement of a complex soil map and soilmorphological investigation in the field, can be applied to discuss soil variations on a vast geomorphic surface where multiple soil-forming factors interact. To test the validity of the method and the soilformation model proposed in this study, we plan to apply the method to other river- and marine-terraces in Taiwan to further discuss the effects of geomorphological, geological, and hydrological conditions on soil development.

\section{Acknowledgements}

We wish to thank L.S. Teng, C.T. Lee, Y. Wang and N.Y. Lin for their informative consultations 
and assistance, and C.S. Liu for providing the valuable borehole data. We also thank Y.C. Lin for improving English, and V.S. Kale, G.J. Retallack, and T. Oguchi, whose critical review greatly improved this manuscript. This study owes much to those who helped with our fieldwork, including R.Y. Chuang, T.P. Chang, K.S. Huang, Y.W. Lin, and M.S. Wu.

\section{References}

Bohn, H.L., McNeal, B.L., O’Connor, G.A., 1985. Soil Chemistry. John Wiley \& Sons, New York.

Central Weather Bureau, 1983-2000. Climatological Data Annual Report: Part I. Surface data.

Chen, C.C., 1976. Soil survey report of Taoyuan County. Research Report, vol. 33. Institute of Agriculture, Taiwan (in Chinese).

Chen, Z.S., 1984. A model for the nowadays soil survey and classification of paddy soils in Taiwan: the study on the seashore district paddy soils in Taoyuan, Taiwan. PhD thesis, Inst. of Agric. Chem., Natl. Taiwan Univ., Taipei (in Chinese).

Chen, Y.G., Liu, T.K., 1991. Radiocarbon dates of river terraces along the lower Tahachi, Northern Taiwan: their tectonic and geomorphic implications. Proc. Geol. Soc. China 34, 337-347.

Chuang, R.Y., Chen, Y.G., Wang, Y., Lee, C.T., 2002. River terraces correlation of lower reach of Tahanchi and its implications on neotectonics. 2002 Annual Meeting of Geological Society of China: Program and Expanded Abstract, pp. 347-349 (in Chinese with English abstract).

Cornell, R.M., Schwertmann, U., 1996. The Iron Oxides: Structure, Properties, Reactions, Occurrence, and Uses. Weinheim, New York.

Coventry, R.J., Taylor, R.M., Fitzpatrick, R.W., 1983. Pedological significance of the gravels in some red and gray earth of Central North Queensland. Aust. J. Soil Res. 21, 219-240.

Daniels, R.B., Gamble, E.E., Nelson, L.A., 1967. Relation between A2 horizon characteristics and drainage in some fine loamy Ultisols. Soil Sci. 104, 364-369.

Evans, C.V., Franzmeier, D.P., 1986. Saturation, aeration, and color patterns in a toposequence of soils in North-Central Indiana. Soil Sci. Soc. Am. J. 50, 975-980.

Fanning, D.S., Fanning, M.C.B., 1989. Soil: Morphology, Genesis, and Classification. John Wiley \& Sons, New York.

Fey, M.V., 1983. Hypothesis for the pedogenic yellowing of red soil materials. Tech. Commun. S. Afr. Dep. Agric. Fish. 18, $130-136$.

Hseu, Z.Y., Chen, Z.S., 1996. Saturation, reduction, and redox morphology of seasonally flooded Alfisols in Taiwan. Soil Sci. Soc. Am. J. 60, 941-949.

Huang, S.C., 1995. The gravel deposits of Taoyuan Terraces. Master Thesis, Inst. of Applied Geol. Natl. Central Univ., Taiwan (in Chinese).
Hurst, V.J., 1977. Visual estimation of iron in saprolite. Geol. Soc. Amer. Bull. 88, 174-176.

Jenny, H., 1941. Factors of Soil Formation: A System of Quantitative Pedology. McGraw-Hill, New York.

$\mathrm{Ku}$, C.C., 1963. Photogeologic study of terraces in Northwestern Taiwan. Proc. Geol. Soc. China 6, 51-60.

Liang, K.W., 1971. A synthesis study of the genesis of reddish brown latosols, yellowish brown latosols and red-yellow podzolic soils in Taiwan. J. Agric. Assoc. China 76, 63-75 (in Chinese).

Lin, S.F., 1991. A preliminary red soil study on terraces in TaoyuanChungli area. Master Thesis, Inst. of Geosci. Natl. Taiwan Univ., Taipei (in Chinese).

Lin, Y.W., 2004. A preliminary study on the soil morphological variation in the Taoyuan-Chungli area. Bachelor thesis, Dept. of Geog. Natl. Taiwan Univ., Taipei (in Chinese).

McFadden, L.D., Knuepfer, P.L.K., 1990. Soil geomorphology: the linkage of pedology and surficial processes. Geomorphology 3, 197-205.

Ollier, C., Pain, C., 1996. Regolith, Soils and Landforms. John Wiley \& Sons, New York.

Osher, L.J., Buol, S.W., 1998. Relationship of soil properties to parent material and landscape position in eastern Madre de Dios, Peru. Geoderma 83, 143-166.

Ota, Y., Shyu, J.B.H., Chen, Y.G., Hsieh, M.L., 2002. Deformation and age of fluvial terraces south of the Choushui River, central Taiwan, and their tectonic implication. West. Pac. Earth Sci. 2, $251-260$.

Schoeneberger, P.J., Wysocki, D.A., Benham, E.C., Broderson, W.D., 1998. Field book for describing and sampling soils. Natural Resources Conservation Service, USDA, National Soil Survey Center, Lincoln, NE.

Schwertmann, U., Taylor, R.M., 1989. Iron oxides. In: Dixon, J.B., Weed, S.B. (Eds.), Minerals in Soil Environment, 2nd ed. Soil Sci. Soc. Am. Book Ser., vol. 1. Soil Sci. Soc. Am., Madison, WI, pp. 379-438.

Soil Survey Staff, 1998. Keys to Soil Taxonomy, 8th ed. Pocahontas Press, Blacksburg.

Sivarajasingham, S., Alexander, I.T., Cady, J.G., Cline, M.G., 1962. Laterite. Advances in Agronomy. Academic Press, New York.

Sung, Q.C., Lu, M.T., Tsai, H., Liew, P.M., 1997. Discussion on the genetics and the correlation of river terraces in Taiwan. J. Geol. Soc. China 40, 31-46.

TANFB (Taiwan Area National Freeway Bureau), 1986. Technical report of preliminary site survey: drilling and on-site tests of the Freeway No.3, Yingge-Kuanchi Section. National Freeway Bureau, Taiwan (in Chinese).

TANFB (Taiwan Area National Freeway Bureau), 1987. Technical report of detailed engineering design (A contract): drilling and on-site tests of the Freeway No. 3, Yingge-Kuanchi Section. National Freeway Bureau, Taiwan (in Chinese).

Valeton, I., 1999. Saprolite-bauxite facies of ferrallitic duricrusts on paleosurfaces of former Pangea. In: Thiry, M., Simon-Coincon, R. (Eds.), Palaeoweathering, Palaeosurfaces and Continental Deposits. International Association for Sedimentologists Special Publication, vol. 27, pp. 153-188. 
Vepraskas, M.J., Wilding, L.P., 1983. Aquic moisture regimes in soils with and without low chroma colors. Soil Sci. Soc. Am. J. 47, 280-285.

Walker, P.H., Coventry, R.J., 1976. Soil profile development in some alluvial deposits of eastern New South Wales. Aust. J. Soil Res. 14, 305-317.

Wan, S.M., Tang, S.F., Liu, C.T., 1985. Composition, structure and properties of clay minerals in laterites on the Linkou Terrace. Hazard mitigation report, vol. 73-48. National Science Council, Taiwan (in Chinese).

Wan, S.M., Chen, S.H., Liu, C.T., 1986a. Basic properties of laterites on the Linkou Terrace. Hazard mitigation report, vol. 74-52A. National Science Council, Taiwan (in Chinese).
Wan, S.M., Chen, S.H., Liu, C.T., 1986b. Mineralogy and chemical properties of weathered cobbles in Linkou Terrace deposits and their relationship with the genesis of laterite. Hazard mitigation report vol. 74-52B. National Science Council, Taiwan (in Chinese).

Wang, Y., Chen, Y., Shyu, J., Chuang, R., Lin, Y., Chung, L., 2002. The active tectonic features in Taoyuan Area, Northwestern Taiwan. AGU 2002 Fall Meeting, T62D-10.

Woods, A.J., 1980. Geomorphology, deformation, and chronology of marine terraces along the Pacific Coast of Central Baja California, Mexico. Quat. Res. 13, 346-364. 